\title{
One-day detection of PCR amplified Chlamydia trachomatis DNA in clinical samples: ELISA versus Southern blot hybridisation
}

\author{
R T J M Roymans, G Onland, B H Postma
}

\begin{abstract}
Aims-To compare ELISA and Southern blot hybridisation for the detection of PCR amplified Chlamydia trachomatis DNA extracted from clinical samples; to assess the value of the ELISA method in a clinical setting.

Methods-DNA was extracted from urogenital samples of 508 patients, purified and amplified using $C$ trachomatis specific primers, one of which was endlabelled with biotin. Amplification products were detected by Streptavidin biotin based ELISA and non-radioactive Southern blotting.

Results-Of the 508 samples, 29 were positive and 479 negative by both methods. No discrepant results were observed. Conclusion-Streptavidin biotin based ELISA and Southern blotting were equally sensitive for detecting PCR amplified $C$ trachomatis DNA. Using ELISA, test results could be generated within a single day.

(F Clin Pathol 1996;49:581-583)
\end{abstract}

Keywords: Chlamydia trachomatis, PCR, ELISA, Southern blotting.

Chlamydia trachomatis is a major cause of sexually transmitted disease worldwide. ${ }^{12}$ In women infection is frequently asymptomatic or may be associated with urethritis, cervicitis and proctitis. Because untreated infections may progress to endometritis, salpingitis and infertility, ${ }^{3}$ early and rapid detection of these infections is essential. Cell culture is labour intensive and depends on the presence of live organisms, which limits time and conditions of transport. As a result, cell culture has largely been replaced by antigen detection by hybridisation with specific antibody and more recently by DNA amplification based assays such as PCR or the ligase chain reaction (LCR).

In an earlier study a non-isotopic hybridisation method for laboratory diagnosis of $C$ trachomatis (Gen Probe) was compared with PCR amplification of plasmid DNA. Although the latter method was more sensitive and specific, unlike Gen Probe, PCR results could not be obtained within a single working day. As rapid turnaround is advantageous to both patient and clinician, a detection method permitting the production of same-day results (PCR ELISA detection kit, Boehringer Mannheim, Mannheim, Germany) was compared with non-radioactive Southern blot analysis. Our aims were to evaluate the sensitivity of the ELISA method compared with Southern blotting for the detection of PCR amplified $C$ trachomatis DNA in patient samples and to assess its usefulness in a clinical setting.

\section{Methods}

SAMPLE COLLECTION AND TREATMENT

Urogenital samples were taken from 508 patients, visiting obstetrics/gynaecology and dermatology clinics of five local hospitals and a low threshold clinic (that is, no prior appointment required) for sexually transmitted diseases, in January and February 1995.

Samples were collected with dacron swabs and placed in Gen Probe transport medium. Upon arrival in the laboratory two drops of Fast Express (to decrease viscosity) were added and the samples were incubated in a water bath at $56^{\circ} \mathrm{C}$ for 10 minutes. Before removal, the swabs were pressed against the wall of the tube. Then $0.1 \mathrm{ml}$ of sample was taken and stored at $4^{\circ} \mathrm{C}$ pending analysis.

ISOLATION AND PURIFICATION OF DNA

DNA extraction was preformed as described by Boom et al. ${ }^{4}$ DNA was adsorbed onto purified silica particles (Celite, Janssen Chimica, Tilburg, The Netherlands). The Celite particles were washed three times with ethanol and once with acetone. DNA was released by addition of $0.1 \mathrm{ml} \mathrm{TE}$ buffer $(10 \mathrm{mM}$ Tris- $\mathrm{HCl}, \mathrm{pH}$ 8.0) and incubated for 15 minutes at $56^{\circ} \mathrm{C}$, during which the suspension was vortexed for a few seconds at five minute intervals. The Celite particles were sedimented by centrifugation for two minutes at $20800 \times g$ and the supernatant used as template. $C$ trachomatis infected Hep-2 cells were used as a control.

POLYMERASE CHAIN REACTION

PCR was performed as described by Claas et $a .^{56}$ The primer set and probe (Isogen, Leiden, The Netherlands; table 1) were derived from sequences of the common endogenous plasmid of $C$ trachomatis. ${ }^{5} 7$

Amplification of target DNA was performed in a $0.1 \mathrm{ml}$ volume containing $10 \mu \mathrm{l} 10 \times \mathrm{PCR}$ solution (100 mM Tris- $\mathrm{HCl}, \mathrm{pH} 9.0 ; 500 \mathrm{mM}$ $\mathrm{KCl} ; 25 \mathrm{mM} \mathrm{MgCl} 2 ; 0.1 \%$ gelatine; $1 \%$ Triton X-100 (all from Merck, Darmstadt, Germany); $20 \mu \mathrm{l} 5 \times \mathrm{dNTP} \operatorname{mix}(1 \mathrm{mM}$ each of dATP, dCTP, dGTP, and dUTP (Boehringer Mannheim)); $1 \mu \mathrm{l}$ of each primer $(500 \mu \mathrm{g} / \mathrm{ml}) ; 1 \mu \mathrm{l}$ DNA polymerase (Sphaero-Q), final concentration 0.25 units per reaction mixture; $58 \mu \mathrm{l}$ 
Table 1 Sequences of oligonucleotides used as primers and probes

\begin{tabular}{ll}
\hline & Oligonucleotide sequence \\
\hline Primer 1 & 5'-GGACAAATCGTATCTCGG-3' \\
Primer 2 (5'-biotin) & 5'-GAAACCAACTCTACGCTG-3' \\
Probe (5'-digoxigenin) & 5'-CGCAGCGCTAGAGGCCGGTCTATTTATGAT-3' \\
Probe (3'-digoxigenin) & 5'-CGCAGCGCTAGAGGCCGGTCTATTTATGAT-3' \\
\hline
\end{tabular}

$\star$ Patent of Boehringer Mannheim, Germany.

aquadest (Brand). The reaction mixture, $90 \mu \mathrm{l}$, was pipetted into an Eppendorf tube and $10 \mu \mathrm{l}$ purified sample DNA was added as well as two drops of glycerol (Merck) to prevent evaporation. Amplification was performed in a PCR processor (Biomed, Ditfurth, Germany) under the following conditions: 60 seconds at $94^{\circ} \mathrm{C}$, 60 seconds at $42^{\circ} \mathrm{C}$ and 60 seconds at $72^{\circ} \mathrm{C}$ for 35 cycles.

PCR reactions were carried out using appropriate positive and negative controls. To prevent false positive results sterile procedures and guidelines for avoiding contamination were followed throughout. Reagents for sample processing and PCR were prepared in separate rooms.

\section{ELISA DETECTION OF PCR PRODUCTS}

All washing steps were performed with prewarmed buffers. Twenty microlitres of amplified product were diluted in $200 \mu \mathrm{l} 1 \times$ SSC buffer with $0.5 \%$ Tween 20 . Streptavidin coated wells were washed once, tapped dry and incubated with $200 \mu \mathrm{l}$ of the diluted product for 30 minutes at $37^{\circ} \mathrm{C}$.

Wells were washed four times, tapped dry and incubated for 10 minutes at room temperature with $200 \mu \mathrm{l} 0.1 \mathrm{M} \mathrm{NaOH}$, washed again and incubated for one hour at $37^{\circ} \mathrm{C}$ with $200 \mu$ diluted 5'-digoxigenin labelled probe (final concentration $10 \mathrm{pmol} / \mathrm{ml}$ hybridisation buffer). Before diluting, the probe was incubated for three minutes at $96^{\circ} \mathrm{C}$ and put on ice. Wells were washed four times, tapped dry and incubated with $200 \mu$ conjugate solution (antidigoxigenin peroxidase) for 30 minutes at $37^{\circ} \mathrm{C}$, washed again four times, tapped dry and incubated with $200 \mu \mathrm{l}$ ABTS substrate $(2,2$ azino-di-[3-ethylbenzthiazoline sulphonate]) for 30 minutes at $37^{\circ} \mathrm{C}$ in the dark. After 15 and 30 minutes' incubation the wells were read in an Anthos ht II reader (Anthos Labtec Instruments, Salzburg, Austria) at $405 \mathrm{~nm}$ (reference filter $492 \mathrm{~nm}$ ) The absorbency of a reagent blank (well $\mathrm{A} 1$, incubated with buffer and substrate only) was subtracted from the reading of each test sample.

SOUTHERN BLOT DETECTION OF PCR PRODUCTS PCR products were analysed by electrophoresis in a $2 \%$ agarose gel (Sphaero-Q, $2 \mathrm{~g}$ agarose $/ 100 \mathrm{ml}$ TBE buffer $(0.05 \mathrm{M}$ Tris- $\mathrm{HCl}$, $0.05 \mathrm{M}$ boric acid, $1 \mathrm{mM}$ EDTA)) at $100 \mathrm{~mA}$ for 30 minutes and stained with $75 \mu$ l ethidium bromide $(1 \mathrm{mg} / \mathrm{ml})$. The banding pattern generated was transferred to a nylon-Z-membrane (Hybond; Bio-Rad, Veenendaal, The Netherlands) in a Bio-Rad semi-dry transblot at 3.5 $\mathrm{mA} / \mathrm{cm}^{2}$ and maximally $25 \mathrm{~V}$ for 30 minutes. Membranes were dried after incubation for 10 minutes in $0.4 \mathrm{M} \mathrm{NaOH}$, prehybridised for 60 minutes at $68^{\circ} \mathrm{C}$ in a Hybaid Micro-4 hybridi- sation oven (Hybaid Ltd, Middlesex, UK) in $10 \mathrm{ml}$ hybridisation solution, containing 0.75 $\mathrm{M} \mathrm{NaCl}, 0.075$ sodium citrate, $\mathrm{pH} 7.0,0.05 \mathrm{M}$ maleic acid, $0.15 \mathrm{M} \mathrm{NaCl}, \mathrm{pH} 7.5,1 \%$ blocking agent (Bio-Rad), $0.02 \%$ SDS (Bio-Rad), $0.1 \% \mathrm{~N}$-lauroylsarcosine (Bio-Rad), sealed in plastic bags and hybridised for 16 hours at $54^{\circ} \mathrm{C}$ in hybridisation solution with the 3'-digoxigenin labelled probe added (final probe concentration $10 \mathrm{pmol} / \mathrm{ml}$ ). Before diluting, the probe was incubated for three minutes at $96^{\circ} \mathrm{C}$ and put on ice. The probe was labelled with digoxigenin using the $3^{\prime}-\alpha$ tailing kit from Boehringer Mannheim, according to the manufacturer's instructions. The following day, membranes were washed twice in washing solution 1 ( $2 \times$ SSC buffer, $0.1 \%$ SDS) and twice in washing solution $2(0.1 \times$ SSC buffer, $0.1 \%$ SDS), each time for five minutes at $54^{\circ} \mathrm{C}$ in a $20 \mathrm{ml}$ volume. Membranes were then incubated for 60 minutes at $37^{\circ} \mathrm{C}$ with anti-digoxigenin alkaline phosphatase (Boehringer Mannheim), washed three times for five minutes at $37^{\circ} \mathrm{C}$ with $10 \mathrm{ml}$ washing solution 2 and once for five minutes at $37^{\circ} \mathrm{C}$ with $10 \mathrm{ml}$ substrate buffer containing $0.1 \mathrm{M}$ Tris- $\mathrm{HCl}, 0.1 \mathrm{M} \mathrm{NaCl}, 0.05 \mathrm{M} \mathrm{MgCl}_{2}, \mathrm{pH}$ 9.5, and incubated with substrate solution (10 $\mathrm{ml} / 50 \mathrm{~cm}^{2}$ membrane) consisting of $9.920 \mathrm{~m}$ substrate buffer, $45 \mu \mathrm{l}$ NBT (100 mg nitroblue tetrazolium (Sigma) in $1.33 \mathrm{ml}$ of a $70 \%$ solution of dimethylformamide (Merck) in aquadest), and $35 \mu \mathrm{l}$ BCIP (100 mg 5-bromo4-chloro-3-indolylphosphate (Sigma) in $2 \mathrm{ml}$ dimethylformamide). When clearly defined bands appeared, the reaction was stopped by removing the substrate solution and washing the membranes in aquadest. Results were read visually and regarded as positive when there was a band at the same position as the positive control.

\section{Results}

Of the 508 samples, 29 were positive and 479 negative for $C$ trachomatis DNA by ELISA and Southern blotting. No discrepant results were observed.

The mean extinction of the negative samples was $0.067 \mathrm{OD}$ and an extinction of $0.150 \mathrm{OD}$ was chosen as a cut off and samples with an extinction $<0.150$ OD were considered negative. All samples with an original extinction of $\geqslant 0.150$ OD had an extinction of $\geqslant 0.150$ OD on retesting and were duly considered positive. The mean extinction of the positive samples was 1.537 OD with a minimum of 0.192 OD and a maximum of $2.361 \mathrm{OD}$.

In this group of patients a prevalence of $C$ trachomatis infection of $5.7 \%$ was recorded by both methods.

\section{Discussion}

Reliable same-day results in laboratory diagnosis of urogenital infections with $C$ trachomatis are important to both patient and clinician, especially in the setting of a low threshold clinic. In this study we compared the sensitivity of an ELISA based one-day detection method for PCR amplified $C$ trachomatis DNA with non-isotopic Southern blotting. Both methods 
had equal sensitivity, no discrepant results were observed and the ELISA proved to be a rapid and reliable detection method.

Before actually starting our study, a panel of known positive and negative samples from an earlier study was used to optimise the ELISA detection method. A maximum difference between mean OD values of positive and negative samples was observed when the probe was incubated for one hour at $37^{\circ} \mathrm{C}$ in a concentration of $10 \mathrm{pmol} / \mathrm{ml}$. Incubation time and concentration of conjugate were as recommended by the manufacturer. An initially occurring rather strong background colour could be eliminated when SSC buffer was replaced by incubation buffer such as used in Southern blotting.

A 3'-digoxigenin labelled probe was used in Southern blot hybridisation. As labelling was done enzymatically, the number of digoxigenin molecules per molecule of probe may vary but as a rule at least three digoxigenin molecules are bound. This has no consequences for probe attachment and may even be of advantage in Southern blotting, giving more intensely coloured bands. To get constant and reproducible results in ELISA the number of digoxigenin molecules attached to the probe should be constant. The chemically labelled probe provided by the manufacturer meets this requirement as one molecule of digoxigenin is attached consistently to each molecule of probe.

In this study we recorded a prevalence of $C$ trachomatis infection of $5.7 \%$. In an earlier study this was $10.5 \%$. The latter prevalence was recorded for a series of 507 patients from the same clinics; there were no differences in male:female ratios or age distributions in each group. In the earlier study samples were mainly taken in August and September; in the present study in January and February, but whether the observed difference in prevalence is accidental or related to the period of sampling is unknown at present.
Genitourinary infection with $C$ trachomatis is especially problematic in women because although it may pass unnoticed initially, its late sequelae can be very serious. Prevention of spread from male to female and rapid treatment can reduce this risk substantially. A rapid and reliable laboratory diagnosis is needed for this purpose. As same-day test results are of advantage in the setting of a low threshold clinic, patients at risk of $C$ trachomatis infection visiting these clinics should benefit most.

PCR followed by ELISA detection can be automated easily. The possibility of including other causative agents of sexually transmitted diseases in this detection system is currently under investigation in our laboratory.

We conclude that ELISA detection of PCR amplified $C$ trachomatis DNA in clinical samples can provide reliable test results on the day of sampling and may contribute substantially to rapid diagnosis in high risk groups.

The authors thank Dr W Quint, Diagnostic Centre, SSDZ, Delft, for help with the manuscript.

1 Centre for Disease Control. Chlamydia trachomatis infection. Policy guidelines for prevention and control. MMWR 1985;35:535-74.

2 Smith JW, Rogers RE, Katz BP, Brickler JF, Lineback PL, Van der Pol B, et al. Diagnosis of chlamydial infection in women attending antenatal and gynaecologic clinics. $f$ Women Microbiol 1987;25:868-72.

3 Brunham RC, Maclean IW, Binns B, Peeling R. Chlamydia trachomatis: its role in tubal infertility. $\mathcal{f}$ Infect Dis 1985;152:1275-82.

4 Boom R, Sol CJA, Salimans MMM, Jansen CL, Wertheimvan Dillen PME, Van der Noordaa J. Rapid and simple method for purification of nucleic acid. $尹$ Clin Microbiol method for purification

5 Claas HCJ, Melchers WJG, Niesters HGM, Van Muyden R, Stolz E, Quint WGV. Infections of the cervix uteri with human papillomavirus and Chlamydia trachomatis. $7 \mathrm{Med}$ Virol 1992;37:54-7.

6 Claas HCJ, Wagenvoort JHT, Niesters HGM, Tio TT, Rijsoort-Vos JH, Quint WGV. Diagnostic value of the polymerase chain reaction for chlamydia detection as determined in a follow-up study. $\mathfrak{f}$ Clin Microbiol 1991;29:42-5.

7 Sriprakash KS, Macavoy ES. Characterization and sequence of a plasmid from the trachoma biovar of Chlamydia trachomatis. Plasmid 1987;18:205-14. 